UDC 616-089.882+616-089+616.314/17-008.1

\author{
(CR. S. Turchyn, V. P. Pyuryk, H. B. Prots, T. L. Malendevych \\ Ivano-Frankivsk National Medical University
}

\title{
Features of compensatory angiogenesis of periodontal tissues in eldery patients with generalised periodontitis influenced tunnel revaskularization and quercetin
}

\begin{abstract}
Summary. This article submissions examination and treatment of 30 persons aged 60-74 years with no signs of periodontal pathology and patients with chronic generalized periodontitis of II-III severity. For the purpose of comparative characteristics of treatments performed using X-rays, reoparodontohrafiy, ultrasound osteometry bone jaws, carried out the analysis of the functional state of the endothelium of vascular endothelial growth factor (VEGF), levels of tumor necrosis factor (TNF) and kapilyaryzation of periodontal tissues to treat and dynamics. All patients were conducted generally accepted treatment of chronic generalized periodontitis, including closed curettage of periodontal pockets. 3 groups of patients on the background of basic therapy of periodontal handled tunnel revascularization with combined use of quercetin per os. It was established that with age in healthy elderly decrease in the number of functioning capillaries per unit area of fabric. The important role of the endothelium in providing adequate compensatory angiogenesis in aging shows the relationship of vascular endothelial growth factor levels of endothelium vazodylatation. Clinical determined that the combined use of revascularization tunnel and quercetin kapilar stabilization drug in treatment of elderly patients with generalized periodontitis stimulates metabolism in periodontal tissues, stabilizes the clinical and radiological picture considerably prolongs remission.
\end{abstract}

Key words: old age, generalized periodontitis, tunnel revascularization , quercetin, compensatory angiogenesis.

\author{
Р. С. Турчин, В. П. Пюрик, Г. Б. Проць, Т. А. Малендевич
}

Івано-Франківський національний медичний університет

\section{Особливості компенсаторного ангіогенезу тканин пародонта в осіб похилого віку, хворих на генералізований пародонтит, під впливом тунельної реваскуляризації та кверцетину}

\begin{abstract}
Резюме. У статті представлено матеріали обстеження та лікування 30 осіб віком 60 - 74 роки без ознак патології пародонта з хронічним генералізованим пародонтитом II - III ступенів тяжкості. 3 метою порівняльної характеристики проведених методів лікування використовували рентгенографію, реопародонтографію, ультразвукову остеометрію кісткової тканини щелеп, виконували аналіз функціонального стану ендотелію, рівня фактора росту ендотелію судин (VEGF), рівня фрактора некрозу пухлин (TNF) та рівня капіляризації тканин пародонта до лікування та у динаміці. Всім хворим було проведено загальноприйняте комплексне лікування хронічного генералізованого пародонтиту, в тому числі закритий кюретаж пародонтальних кишень. Хворим третьої групи на фоні базової терапії поводили тунельну реваскуляризацію пародонта з поєднаним використанням кверцетину per os. Bстановлено, що з віком у практично здорових людей похилого віку спостерігається зниження кількості фрункціонуючих капілярів на одиницю площі тканини. Важливу роль ендотелію в забезпеченні адекватного компенсаторного ангіогенезу при старінні доводить наявність взаємозв'язку рівня фактора росту ендотелію судин з рівнем ендотелійзалежної вазодилатації. Клінічно визначено, що поєднане
\end{abstract}


використання тунельної реваскуляризації та капіляростабілізуючого препарату «Кверцетин» у комплексному лікуванні осіб похилого віку, хворих на генералізований пародонтит, стимулює обмінні процеси в тканинах пародонта, стабілізує клінічну та рентгенологічну картину, значно пролонгує період ремісії.

Ключові слова: похилий вік, генералізований пародонтит, тунельна реваскуляризація, кверцетин, компенсаторний ангіогенез.

\author{
Р. С. Турчин, В. П. Пюрык, Г. Б. Проць, Т. $\Lambda$. Малэндэвич
}

Ивано-Франковский национальный медицинский университет

\title{
Особенности компенсаторного ангиогенеза тканей пародонта у лиц пожилого возраста, больных генерализованным пародонтитом, под влиянием туннельной реваскуляризации и кверцетина
}

Резюме. В статье представлены материалы обследования и лечения 30 человек в возрасте 60 - 74 года без признаков патологии пародонта с хроническим генерализованным пародонтитом II - III степеней тяжести. С целью сравнительной характеристики проводимых методов лечения использовали рентгенографию, реопародонтографию, ультразвуковую остеометрию костной ткани челюстей, проводили анализ функционального состояния эндотелия, уровня фактора роста эндотелия сосудов (VEGF), уровня фактора некроза опухоли (TNF) и уровня капилляризации тканей пародонта до лечения и в динамике. Всем больным было проведено общепринятое комплексное лечение хронического генерализованного пародонтита, в том числе закрытый кюретаж пародонтальных карманов. Больным третьей группы на фоне базовой терапии была произведена туннельная реваскуляризация пародонта с совместным использованием кверцетина per os. Установлено, что с возрастом у практически здоровых пожилых людей наблюдается снижение количества функционирующих капилляров на единицу площади ткани. Важную роль эндотелия в обеспечении адекватного компенсаторного ангиогенеза при старении доказывает наличие взаимосвязи уровня фактора роста эндотелия сосудов с уровнем эндотелийзависимой вазодилатации. Клинически определено, что сочетанное использование туннельной реваскуляризации и капилляростабилизирующего препарата «Кверцетин» в комплексном лечении лиц пожилого возраста, больных генерализованным пародонтитом, стимулирует обменные процессы в тканях пародонта, стабилизирует клиническую и рентгенологическую картину, значительно пролонгирует период ремиссии.

Ключевые слова: пожилой возраст, генерализованный пародонтит, туннельная реваскуляризация, кверцетин, компенсаторный ангиогенез.

Introduction. The course of chronic generalized periodontitis (CHP) in the elderly is characterized by a predominance of destructive processes of inflammation, increased cell apoptosis effects, reduced osteogenic activity, microcirculation, progressive tissue hypoxia, decreased reparative capacity ligaments tooth $[1,2,6]$.

In the chain of causation, microcirculation changes are secondary in nature. Exploring the nature of periodontal microcirculation in normal and pathology it gives information about the nature of different periodontal disease, suggests a functional state authority and evaluates effectiveness used in dental surgery treatments.

According to some authors vasospasm can lead to predtrombotychnyh and thrombotic processes. It is known that the vascular wall is efferent control of the process of blood coagulation and fibrinolysis. Therefore, structural changes in the form of enzymatic processes leading to disruption of the aggregation and adhesion of blood cells and vascular permeability . Violation is tool capillary 
- the connective tissue structure and physical state of red blood cells and platelets are important pathogenetic link in symptom formation by CHP $[1,3,5]$.

In practice medicine successfully quercetin with angioprotective, membrane, immunemodulating effects. This drug has anti-oxidant effect, improves blood circulation, speeds healing and affects the processes of bone remodeling . But today is little known effect of quercetin on metabolism and growth factors pruzhnoelastychni properties, structural and functional state of the microcirculation of periodontal tissues in elderly patients with CHP .

Objective: to increase the effectiveness of surgical treatment of patients with chronic generalized periodontitis of II-III degree of severity by the combined use of revascularization tunnel and quercetin.

Object and methods. Under our supervision there were 30 people aged 60-74 years with severe comorbidities who underwent combined treatment on CHP II-III severity. To assess the periodontal status and diagnosis of periodontal diseases classification used by Danilevsky MF (1994). Depending on the conducted treatment patients were divided into 3 groups: group 1 (group) - 10 people with no signs of periodontal pathology; Group 2 - 10osib who underwent the conventional treatment according to the protocol approved by the Ministry of Health to provide medical care (ICD k 05.31) and closed curettage of periodontal pockets ; Group 3 - 10 people, which in addition to traditional treatment used tunnel revascularization with combined use of quercetin orally. Operation of tunnel revascularization was performed under local anesthesia and was the formation of subperiosteal tunnel curved spokes Kirschner (diameter $1 \mathrm{~mm}$ ) with vestibular side, departing at 5-8 $\mathrm{mm}$ from the edge of the gums in the area between the first molars respective jaw. The purpose of this intervention was to create conditions for directional vascular growth in the affected areas of periodontal disease. This operation was performed on the fifth day of the baseline treatment period by an average of 15 days. Quercetin (registration certificate № UA / 0119/ 01/01) granules $2 \mathrm{~g}$ administered three times per day during the treatment period.

The functional state of the endothelium was studied by laser Doppler floumetry on the device
Lucky - 2 (Russia). The level of vascular endothelial growth factor VEGF (Vascular endothelial growth factor) were determined in serum by enzyme - linked immunosorbent assay (ELISA) using a set of chemicals firm Bender Medsystems (Austria). The level of tumor necrosis factor (TNF) were determined in serum by ELISA using reagents recruitment firm Vector Best (Russia). Level kapilyaryzation periodontal tissues was assessed by the method of biomicroscopy in capillaroscope TM-1. For the purpose of comparative characteristics of methods of surgical treatment performed to assess data radiography and ultrasound osteometriyi bone of the jaws (osteometr computer - $01 \mathrm{C}$ ), the qualitative and quantitative characteristics curves reohrafichnyh alveolar process of the jaws (rheograph Reo - Spectrum - 2, Russia) before treatment and after 6 months after surgery.

The reliability difference between the average quantitative values of the samples was determined by Student's t - test. In order to clarify the nature and extent of the relationship of the various parameters measured correlation coefficients (r).

Results and discussion. According to the data, with age, there is a relative decrease in capillary density, as evidenced by an increase in the percentage of capillary deficit in elderly groups 2 and 3 compared with group 1 (Table 2).

As proven in laboratory parameters of physiological compensatory angiogenesis activity is the level of vascular endothelial growth factor, we have investigated the level indicator appointed in three groups of subjects. Thus, patients in group 2 compared with group 1 elderly observed a slight increasetion, which may be due to the need to maintain normal perfusion conditions by age - dependent changes in the metabolism of organs and tissues. In determining the level of VEGF in the elderly was noted: in group 1 studied its level continued to rise according to the needs of the age, and in groups 2 and 3 - o terihalos lack of increase in this index (Table 1).

It is necessary to note the presence of correlation of vascular endothelial growth factor with the number of functioning capillaries according biomicroscopy periodontal $(r=0,39)$, indicating the important role of physiological compensatory angiogenesis to provide the optimum level kapilyaryzatsiyi tissues during aging.

On the objectivity of this conclusion are the results of periodontal biomicroscopy. So in the 
elderly 2 and 3 groups observed a significant lower density of functioning capillaries compared with 1 group of people with almost healthy periodontium. Noteworthy that in the 2nd and 3rd group of older people with capillary sparsity not tend to vascular endothelial growth factor, unlike in 1 group with optimal kapilyaryzatsiyeyu, which appointed the level indicator was relatively sufficient.
Our results show that the number of functioning capillaries in the periodontal tissues of patients 2 and 3 groups significantly lower than in group 1, which undoubtedly, among other factors should be regarded as a prerequisite to the development of perfusion disorders, age dependent and hypoxia syndrome kapilyarotrofichnoyi failure.

Table 1. The level of vascular endothelial growth factor (VEGF) in the serum of elderly patients suffering from CHP, pg / ml

\begin{tabular}{|l|c|c|c|c|c|}
\hline \multirow{2}{*}{ Index } & \multicolumn{3}{|c|}{ Before treatment } & \multicolumn{2}{c|}{6 months after treatment } \\
\cline { 2 - 6 } VEGF & group 1 & group 2 & group 3 & group 2 & group 3 \\
\cline { 2 - 6 } & $242,3 \pm 8,97$ & $220,25 \pm 7,51$ & $220,25 \pm 7,51$ & $223,15 \pm 6,42$ & $238,30 \pm 8,15$ \\
\hline
\end{tabular}

Table 2. The number of functioning capillaries per unit area of tissue of elderly patients suffering from CHP according biomicroscopy periodontal tissues

\begin{tabular}{|l|c|c|c|c|c|}
\hline \multirow{2}{*}{ Index } & \multicolumn{3}{|c|}{ Before treatment } & \multicolumn{2}{c|}{6 months after treatment } \\
\cline { 2 - 6 } & group 1 & group 3 & group 2 & group 3 & group 2 \\
\cline { 2 - 6 } $\begin{array}{l}\text { The number } \\
\text { of capillaries } \\
1 \mathrm{~mm}\end{array}$ & $11,18 \pm 0,55$ & $6,25 \pm 0,35^{*}$ & $6,18 \pm 0,35^{*}$ & $8,21 \pm 0,15^{*}$ & $9,10 \pm 0,14^{*}$ \\
\hline
\end{tabular}

Note. ${ }^{*}$ - significant changes compared with the group of healthy individuals, $\mathrm{p}<0,05$.

In the study of the relationship marker of intravascular inflammation (tumor necrosis factor) with the level of vascular endothelial growth factor has been shown that in 2 or 3 groups of patients to treatment observed increase of TNF. Were observed correlation of necrosis factor down to the level of vascular endothelial growth factor, which indicates the absence of stimulating effect on intravascular inflammatory process physiological compensatory angiogenesis in healthy elderly (Table 3).

The main physiological mechanisms support a satisfactory level of activity of physiological compensatory angiogenesis is the integrity and safety of functional endothelium, including NO - synthase sufficient activity as vascular endothelium is the site of synthesis and action of basic growth factors $[4,6]$. To determine the role of the functional state of the endothelium in physiological compensatory angiogenesis activity in elderly patients with HHP, we have investigated the levels of $\mathrm{NO}$ - synthase activity in endothelial groups examined through LDF test with reactive hyperemia.
In the study of NO - synthase activity of endo dents significant differences of endothelium vasodilation in 1 group of healthy subjects was optimal and consistent physiological agerelated changes. In the 2 nd and 3rd group of elderly people observed a general tendency to decrease in endothelium vasodilation, but in group 1 patients with sufficient levels of vascular endothelial growth factor percentage growth rate of microcirculation (PM) was significantly higher than in those with insufficient levels of VEGF (Table 1).

The data show a decrease in an assetness of endothelial NO - synthase with age, indicating a decrease in the production of nitric oxide and leads to disruption of the protective properties of the endothelium during aging.

In conducting the correlation analysis, it was found in patients 2 and 3 groups observed the relationship of vascular endothelial growth factor levels and endothelium vasodilation $(r=0,37)$, indicating the important role of the endothelium in providing adequate compensatory angiogenesis in periodontal tissues. 
Table 3. The level of tumor necrosis factor (TNF) in the serum of elderly patients suffering from CHP, pg / ml

\begin{tabular}{|l|c|c|c|c|c|}
\hline \multirow{3}{*}{ Index } & \multicolumn{3}{|c|}{ Before treatment } & \multicolumn{2}{c|}{6 months after treatment } \\
\cline { 2 - 6 } & group 1 & group 3 & group 1 & group 3 & group 1 \\
\cline { 2 - 6 } $\mathrm{pg} / \mathrm{ml}$ & $1,65 \pm 0,08^{*}$ & $1,73 \pm 0,15^{*}$ & $1,73 \pm 0,05^{*}$ & $1,71 \pm 0,05^{*}$ & $1,67 \pm 0,03^{*}$ \\
\hline
\end{tabular}

Note. ${ }^{*}$ - Significant changes compared with the group of healthy individuals, $\mathrm{p}<0,05$.

Patients 2 and 3 groups for the surgical treatment of CHP set circulatory deficiency (if indicated PTAs, defense, PVV, IEC), reduced vascular tone and elasticity of blood vessels, and in turn - the deterioration of trophic tissue. Dynamics of reohram in elderly patients with CHP 3 groups at 6 months after surgery tunnel revascularization was more pronounced compared with similar patients in group 2 . The studies found that patients in groups 2 and 3 during 6 months of follow - going improvement of blood circulation in the periodontal tissues, but positive results were more pronounced in patients 3 groups. After 6 months of treatment qualitative and quantitative indicators reohram (PTAs, defense, PVV, IEC) in 3 groups of patients indicate a steady improve regional circulation alveolar processes of the jaws and long - term periods after surgery CHP.

$\mathrm{X}$ - ray picture and performance of ultrasonic osteometriyi in both groups of patients before surgery showed the presence of pathological changes in periodontal tissues: reduced height compact plate of the alveolar process of the jaw and bone demineralization. Performance of X - ray and ultrasound examination in most patients 2 and 3 groups after surgery upgraded . When $\mathrm{X}$ - ray 6 months after surgery in 10 patients and 3 group 4 group 2 patients was observed stabilization process, as manifested in the seal and a clear definition of compact plate of the alveolar process of the jaw.

Results osteometrychnyh studies indicate a significant difference between the treatment of patients 2 and 3 groups. After 6 months, after an

\section{References}

1. Carmeliet P. Mechanisms of angiogenesis and arterio - genesis / P. Carmeliet // Nat. Med. - 2009. Vol. 6 (4). - P. $389-395$.

2. Schultz A. Interindividual heterogeneity in the hypoxic regulation of VEGF: Significance for the development of the coronary artery collateral circulation / A. Schultz, L. Lavie, I. Hochberg // Circulation. - 1999. - P. 547-552.

3. Dulak J. Nitric Oxide Induces the Synthesis of Vascular Endothelial Growth Factor by Rat Vascular operation time of the ultrasonic waves in the 2 groups of patients was $18,90 \pm 0,15$ microseconds, 3 groups of patients $-16,31 \pm 0,05$ microseconds $(p<0,05)$. At 6 months after surgery in 4 patients in group 2 and group 3 of 10 patients the passage of ultrasound decreased that testimony positive processes of mineralization of bone.

Conclusions. With age, the elderly, a decrease in the number of functioning capillaries per unit area of fabric. The important role of physiological compensatory angiogenesis to provide sufficient kapilyaryzation tissues during aging confirms the correlation of vascular endothelial growth factor with the number of functioning capillaries according biomicroscopy periodontal tissues.

Activity compensatory angiogenesis in the elderly is not associated with intravascular inflammatory activity, as evidenced by the lack of correlation of inter connection vascular endothelial growth factor levels of tumor necrosis factor. The important role of the endothelium in providing adequate compensatory angiogenesis in aging shows the relationship of vascular endothelial growth factor levels of endothelium vasodilation.

After surgery the tunnel revascularization using quercetin in treatment improves blood flow in the area where held manipulation, warned the development of destructive processes in the periodontium resulting in positive dynamics of clinical, radiological and osteometrychnyh performance improvement is caused by the microcirculation and metabolism of bone.

Smooth Muscle Cells / J. Dulak, A. Jyzkowicz, A. Dembinska-Kiec // Arteriosclerosis, Thrombosis, and Vascular Biology. - 2000. - P. 659-666.

4. Dishart K. L. Gene therapy for cardiovascular / K. L. Dishart, L. M. Work, L. Denby // J. Biomed. Biotechnol. - 2003. - № 2. - P. 138-148.

5. Fukuda S. Angiogenic signal triggered by ischemic stress induced myocardial repair in rat during chronic infarction / S. Fukuda // J. Mol. Cell Cardiol. - 2004. - № 4 . - P. 547 - 559 . 